by Scott E. Bryan ${ }^{1}$, Alex. G. Cook ${ }^{2}$, Charlotte M. Allen ${ }^{3}$, Coralie Siegel ${ }^{1}$, David J. Purdy ${ }^{4}$, James S. Greentree ${ }^{l}$ and I. Tonguc Uysal ${ }^{5}$

\title{
Early-mid Cretaceous tectonic evolution of eastern Gondwana: From silicic LIP magmatism to continental rupture
}

\author{
${ }^{1}$ Biogeoscience, Queensland University of Technology, 1 George Street, Brisbane, QLD 4001, Australia. E-mail: scott.bryan@qut.edu.au; \\ coralie.siegel@qut.edu.au; james.greentree@qut.edu.au \\ ${ }^{2}$ Queensland Museum, P.O. Box 3300 South Brisbane, QLD 4101, Australia. E-mail: alex.cook@qm.qld.gov.au \\ ${ }^{3}$ Research School of Earth Sciences, Australian National University, Canberra, ACT 2601, Australia. E-mail: charlotte.allen@anu.edu.au \\ ${ }^{4}$ Geological Survey of Queensland, Mines and Energy, Department of Employment, Economic Development and Innovation, Level 11, 119 \\ Charlotte Street, Brisbane, QLD 4001, Australia. E-mail: david.purdy@deedi.qld.gov.au \\ ${ }^{5}$ Queensland Geothermal Energy Centre of Excellence, The University of Queensland, St Lucia, QLD 4001, Australia. E-mail: t.uysal@uq.edu.au
}

The Early-mid Cretaceous marks the confluence of three major continental-scale events in eastern Gondwana: (1) the emplacement of a Silicic Large Igneous Province (LIP) near the continental margin; (2) the volcaniclastic fill, transgression and regression of a major epicontinental seaway developed over at least a quarter of the Australian continent; and (3) epeirogenic uplift, exhumation and continental rupturing culminating in the opening of the Tasman Basin c. 84 Ma. The Whitsunday Silicic LIP event had widespread impact, producing both substantial extrusive volumes of dominantly silicic pyroclastic material and coeval first-cycle volcanogenic sediment that accumulated within many eastern Australian sedimentary basins, and principally in the Great Australian Basin system (>2 $\mathrm{Mkm}^{3}$ combined volume). The final pulse of volcanism and volcanogenic sedimentation at c. 10595 Ma coincided with epicontinental seaway regression, which shows a lack of correspondence with the global sea-level curve, and alternatively records a wider, continental-scale effect of volcanism and rift tectonism. Widespread igneous underplating related to this LIP event is evident from high paleogeothermal gradients and regional hydrothermal fluid flow detectable in the shallow crust and over a broad region. Enhanced $\mathrm{CO}_{2}$ fluxing through sedimentary basins also records indirectly, large-scale, LIP-related mafic underplating. A discrete episode of rapid crustal cooling and exhumation began c. 100-90 Ma along the length of the eastern Australian margin, related to an enhanced phase of continental rifting that was largely amagmatic, and probably a switch from wide-more narrow rift modes. Along-margin variations in detachment fault architecture produced narrow (SE Australia) and wide continental margins with marginal, submerged continental plateaux (NE Australia). Long-lived NE-trending cross-orogen lineaments controlled the switch from narrow to wide continental margin geometries.

\section{Introduction}

Rifting, magmatism and sedimentation have fundamentally shaped the modern eastern Australian margin and many, often disparate studies have pin-pointed the Early Cretaceous as when these tectonic-driven processes began affecting and shaping the modern-day eastern margin. As a result of the spatial-temporal overlap of volcanism and extension (e.g., Ewart et al., 1992; Bryan et al., 2000; Och et al., 2009), the eastern margin of Australia has been reinterpreted as a volcanic rifted margin (Bryan et al., 1997), but which shows some important differences to better known volcanic rifted margins such as those surrounding the Atlantic and Red Sea (e.g., Menzies et al., 2002). In general, all these magmatically-enhanced rifted margins extend laterally over distances of 2,000 km (Armitage et al., 2010) and potentially have high significance to Earth history, being linked to mass extinctions, changes in global climate, and natural resource generation (Svensen et al., 2004; Storey et al., 2007).

The purpose of this contribution is to emphasise some important aspects of the Early Cretaceous history of eastern Gondwana: (1) the close spatial-temporal relationship of Silicic Large Igneous Province (LIP) magmatism to continental rifting and passive margin formation, and how complexities in the rifting process have hindered an appreciation of the immensity of magmatism during the Early Cretaceous in eastern Australia; (2) the eruptive output of this igneous province and to provide an upward revision of extrusive volume estimates following recent studies along the eastern Australian margin; 
(3) that a large proportion of the erupted products are preserved as huge volumes of coeval volcanogenic sediment in adjacent sedimentary basin systems; and (4) important long-term volcanic and compositional trends of magmatism.

\section{The Eastern Australian Volcanic Rifted Margin}

The Cretaceous-Cenozoic eastern Australian volcanic rifted margin is c. $4,500 \mathrm{~km}$ long and mirrors the Jurassic-Cretaceous basalt-dominated volcanic rifted margin of western Australia some $2,500-4,000 \mathrm{~km}$ to the W. Over most of its length, the eastern margin is flanked by a major continental-scale physiographic feature (the Great Dividing Range; Figure 1; e.g., Ollier, 1982). The origins of both these rifted margins were initially located in intraplate continental positions, but subsequent rifting to form new ocean basins has also resulted in large portions of extended continental crust and syn-rift successions now residing offshore (Figure 1). The Whitsunday Silicic LIP was the major magmatic precursor event to rifting along the eastern Australian margin, and gives the rifted margin its volcanic character. This section summarises a number of aspects of the development of this rifted margin beginning in the Early Cretaceous.

\section{Nature of pre-rift margins to the Whitsunday Silicic LIP}

Two major continental sedimentary basin systems, the Great Australian and Otway-GippslandBass basins in NE and SE Australia, respectively (Figure 1) flanked the Whitsunday Silicic LIP along its western margin. These pre-existing basin systems were major repositories for huge volumes of volcaniclastic material erupted from the Silicic LIP (Bryan et al., 1997). In contrast, the eastern margin of the Silicic LIP was an elevated margin or likely bordered by rift basin complexes developed coincident with Silicic LIP magmatism. Compiled geophysical data indicate that several offshore basins (Central and Western Rift provinces of the Lord Howe Rise, New Caledonia, Queensland and Townsville) began opening in the Early Cretaceous (Wellman et al., 1997; Willcox and Sayers, 2001; Willcox et al., 2001; Lafoy et al. 2005). However, recent ODP drilling (leg 194) on the Marion Plateau to the E of the Whitsunday Silicic LIP (Figure 1) intersected Jurassic (162 $\pm 0.9 \mathrm{Ma}$; Karner and John, unpublished data, 2002) intraplate alkali basalts beneath Cenozoic Oligocene-Miocene sedimentary rocks (Isern et al., 2002), defining an eastern limit to the Silicic LIP. These Jurassic intraplate alkali basalts reinforce an intraplate passive margin setting for NE Australia during the Jurassic and Cretaceous and preclude the Whitsunday Silicic LIP as representing some backarc extensional magmatic event.

\section{Duration and relative timing of rifting and magmatism}

Rifts in the interior of continents that evolve to form large ocean basins typically last for 30 to $80 \mathrm{Myr}$ and longer before complete rupture of the continent and onset of sea-floor spreading (Umhoefer, 2011). Silicic LIP magmatism immediately preceded large-scale continental rifting that began in the middle Cretaceous and led to: (1) the opening of a series of basins, some floored by oceanic crust

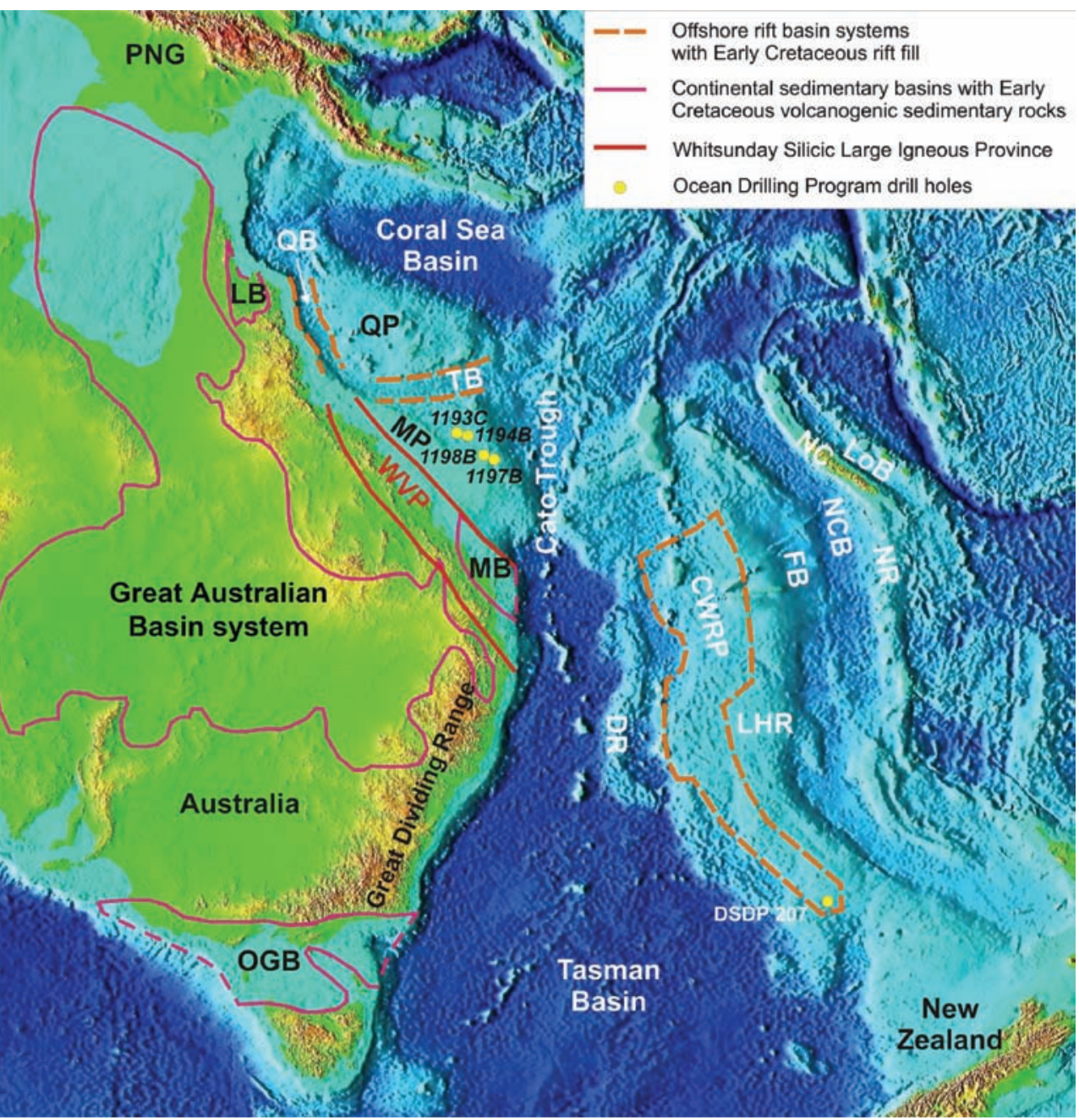

Figure 1 Topographic-bathymetric map of the SW Pacific with the tectonic elements referred to in text labelled. Drill holes, 1193C, 1194B, 1197B and 1198B are from ODP Leg 194 on the Marion Plateau (MP). Abbreviations: CWRP, Central and Western Rift Provinces of the Lord Howe Rise (LHR); DR, Dampier Ridge; FB, Fairway Basin; LB, Laura Basin; LoB, Loyalty Basin; MB, Maryborough Basin; NC, New Caledonia; NCB, New Caledonia Basin; NR, Norfolk Ridge; OGB, Otway-Gippsland-Bass basins; PNG, Papua New Guinea; QB, Queensland Basin; QP, Queensland Plateau; TB, Townsville Basin; WVP, Whitsunday Volcanic Province. 
(Tasman Basin-Cato Trough-Coral Sea Basin system, South Loyalty Basin) with others by extended continental crust (New Caledonia, Lord Howe, Middleton, Queensland, Townsville and Capricorn Basins), and (2) the dispersion of rifted microcontinents (e.g., Lord Howe Rise, Dampier Ridge, New Caledonia-Norfolk Ridge, Queensland Plateau) away from the eastern margin of Australia (Figure 1). The Tasman-Cato Trough-Coral Sea Basin system is the largest of the basin systems, with sea floor-spreading occurring between the Cretaceous and Paleocene (chron 33-24, 84-52 Ma; Lafoy et al., 2005). The Tasman Basin is triangular in outline, the result of a sea floor-spreading system that propagated northward in a zipper-like fashion over time, resulting in the separation of the Lord Howe Rise microcontinent (Figure 1) from eastern Australia (Willcox et al., 2001).

The end-result of Cretaceous-Cenozoic rifting of eastern Gondwana is that the Silicic LIP is now largely dismembered and only part of the province remains intact (Figures 1 and 2). This is primarily because break-up and sea floor-spreading processes were complex, involving the movement of several microplates, the failure of several rifts and consequent ridge jumps by the sea floor-spreading system (Gaina et al., 1998, 2003; Willcox et al., 2001). Of interest is that initial half spreading rates of the Tasman Basin from 83-79 Ma are indicated to have been unusually slow ( $4 \mathrm{~mm} /$ year) causing the basin to only open by c. $30 \mathrm{~km}$ during this time (Gaina et al., 1998). The initially slow rates of rifting may be an important factor in explaining the extended period between Silicic LIP magmatism (c. 130-95 Ma) and the first appearance of new oceanic crust in the earliest Campanian (c. $84 \mathrm{Ma}$ ). Understanding the complexities of the rifting processes and dismembering of the Silicic LIP are important because they have been major factors in hindering the recognition of: (1) the scale and magnitude of Early Cretaceous silicic magmatism; and (2) the tectonic setting and relationship of separated but coeval igneous and volcanosedimentary terranes in eastern Gondwana. Past interpretations of individual terranes in isolation have led to contradictory tectonic models for the Early Cretaceous of eastern Gondwana.

\section{Regional thermal and hydrothermal effects}

In addition to the main magmatic expression, this Silicic LIP and rifting event also had regional thermal and hydrothermal effects associated with mantle $\mathrm{CO}_{2}$ degassing. Numerous apatite fission track thermochronology studies in eastern Australia have recorded a major Early Cretaceous heating event (coincident with Silicic LIP magmatism), with increases in maximum Cretaceous paleotemperatures toward the margin, followed by mid-Cretaceous cooling beginning c. 100-95 Ma (e.g., O’Sullivan et al., 1995, 1996, 1999; Marshallsea et al., 2000; Kohn et al., 2002, 2003). These studies have generally concluded that: (1) Cretaceous heating was due to a greater depth of burial and increased paleogeothermal gradient (crustal heat flow), and (2) mid-Cretaceous cooling occurred in response to kilometre-scale denudation associated with rifting along the eastern Australian margin, leading to the formation of a passive margin mountain range (the Great Dividing Range of eastern Australia). A widely recognised paleomagnetic overprint affecting the crust of southern and eastern Australia is also attributed to this Early to midCretaceous thermal event (e.g., Thomas et al., 2000). Significant regional mantle $\mathrm{CO}_{2}$ degassing and mineral trapping occurred during the Cretaceous, which is manifested by widespread authigenic carbonate and clay mineral precipitation throughout the late Permian

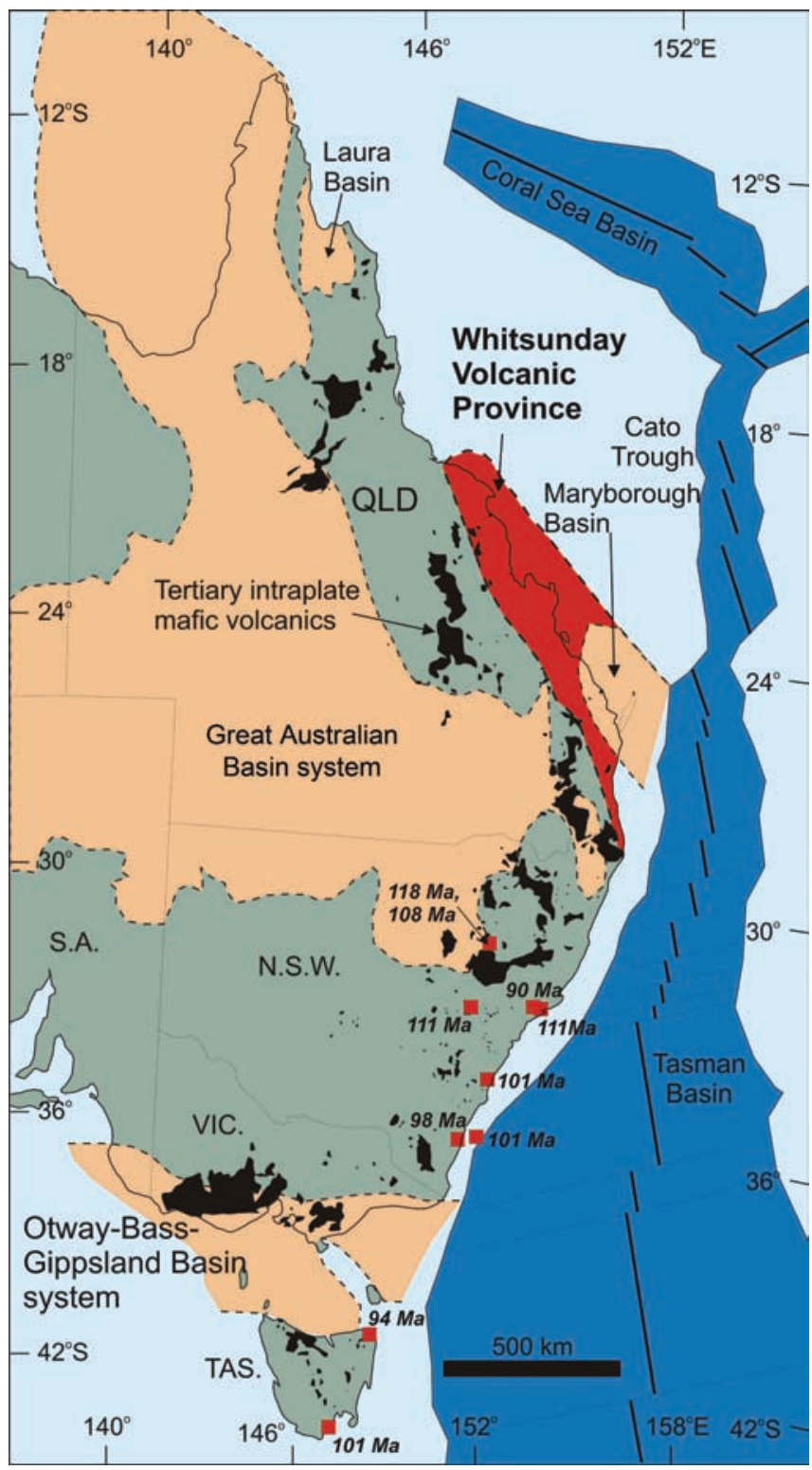

Figure 2 Location of the Whitsunday Volcanic Province and Early Cretaceous sedimentary basins of eastern Australia that contain $>1.4 \mathrm{Mkm}^{3}$ of coeval LIP-derived volcanogenic sediment (Bryan et al., 1997). Red squares are locations of dated igneous rocks (ages in italics) along the SE margin of Australia. Intraplate alkaline volcanism (80-0 Ma) is shown in black.

in the Bowen-Gunnedah-Sydney basin system and well inboard of the Whitsunday Silicic LIP along the eastern Australian coast (Baker et al., 1995; Uysal et al., 2000, 2011; Golab et al., 2006). These new data raise the possibility that mantle and magmatic gas emissions may not be restricted to eruptive events in the LIP and much greater greenhouse gas emissions may occur over much larger areas during LIP and rifted margin events.

\section{Post-rift intraplate alkaline volcanism}

The Whitsunday Silicic LIP is like many other LIPs in being followed by asthenospheric-derived or "hotspot"-style mafic volcanism. This intraplate alkali basaltic volcanism shows a clear spatial association with the passive margin mountain range, forming 
a broken belt 4,400 km long along the 'highlands' of eastern Australia (Figures 1 and 2). Intraplate alkaline volcanism has continued to the Holocene, occurring within $500 \mathrm{~km}$ of the coastline, and has an extrusive volume of $>20,000 \mathrm{~km}^{3}$ (e.g., Johnson, 1989). However, this volcanism is part of a much broader, mostly basaltic and alkaline igneous province emplaced across continental and oceanic lithosphere in the SW Pacific Ocean region during the Cenozoic (Finn et al., 2005). For eastern Australia, several features of note are that: (1) an c. $15 \mathrm{Myr}$ hiatus occurred between the terminal phases of Whitsunday Silicic LIP magmatism and the first expressions of intraplate mafic volcanism; this hiatus correlates with a period of uplift, erosion and abrupt crustal cooling of the eastern margin, based on the apatite fission track data; (2) the widespread eruption of intraplate alkali basalts overlapped in time with sea floor-spreading in the Tasman Basin, and in particular, that the onset of intraplate mafic volcanism at c. $80 \mathrm{Ma}$ (Sutherland et al., 1996) coincided with a more than fivefold increase in the spreading rate to $22 \mathrm{~mm} /$ year in the Tasman Basin at $79 \mathrm{Ma}$ (Gaina et al., 1998; Willcox et al., 2001); (3) some of the youngest intraplate mafic volcanism has occurred in northern and southern Australia and at the extremities of the intraplate volcanic belt; and (4) the most primitive basalt geochemical signatures from the Whitsunday Silicic LIP overlap those of the younger within-plate alkaline basalts of eastern Australia (Ewart et al., 1992), indicating a 'geochemical connection' between pre-break-up Silicic LIP magmatism and post-break-up intraplate volcanism (Bryan et al., 2000). In summary, the time-space relationships between magmatism, highlands uplift and sea floor-spreading are most readily explained by detachment models where eastern Australia is interpreted as an upper-plate passive margin (e.g., Lister and Etheridge, 1989).

\section{The Whitsunday Silicic Large Igneous Province}

Early-mid Cretaceous (c. 135-95 Ma) magmatic products along the eastern margin of Australia define the Whitsunday Silicic LIP, which is the largest of the world's Silicic LIPs where the eruptive output $\left(>2.5 \mathrm{Mkm}^{3}\right)$ and preserved areal extent of volcanism and its products surpass that of many other LIPs (Bryan et al., 1997, 2000; Bryan, 2007). Silicic LIP magmatism occurred as a within-plate, silicic-dominated pyroclastic volcanic belt, $>2,500$ x $300 \mathrm{~km}$, roughly coincident with the present eastern Australian plate margin (Figure 1). The Whitsunday Silicic LIP is defined by the following igneous, volcanosedimentary and tectonic elements of Early Cretaceous age: (1) the Whitsunday Volcanic Province of NE Australia; (2) scattered igneous intrusions and volcanic rocks along the SE Australian margin; (3) the Great Australian and Otway-Gippsland-Bass basin systems of NE and SE Australia, respectively; and (4) submerged volcanic and rift-fill sequences on marginal continental plateaux and troughs.

\section{Whitsunday Volcanic Province}

The Early Cretaceous Whitsunday Volcanic Province is defined here to encompass all igneous rocks preserved in the relatively intact extension of the Silicic LIP along the NE Australian margin (Figures 1 and 2). It was preserved on the Australian continental margin following an eastward ridge jump of the Tasman spreading ridge into the Cato Trough at c. $65 \mathrm{Ma}$ (Falvey and Mutter, 1981).

The uplift and exhumation history, related to rifting of the margin, has played an important role in the preservation and general character of Early Cretaceous igneous rocks in Queensland. Recent dating efforts, principally as part of regional mapping programs, have increasingly recognised a much greater extent and number of Cretaceous igneous rocks through eastern Queensland (Figure 3). Many of these units for example, had previously been mapped as Carboniferous or Permian in age. Distinct differences in preservation occur along the Queensland margin (Figure 3), and a boundary between dominantly volcanic successions and granitic intrusions can be delineated. This newly compiled distribution of Early Cretaceous igneous rocks (Figure 3) demonstrates very different and abrupt changes in exhumation history from W-E across the northern (Whitsunday) region, with volcanic rocks limited to coastal sections and the Whitsunday Islands. Further S through central Queensland, volcanic rocks are preserved much further inboard of the margin, whereas in SE Queensland, volcanic rocks are principally restricted in occurrence to near the margin (Maryborough Basin) and intrusive rocks predominate. These along margin variations relate to major cross-orogen lineaments (Figure 3), which have partitioned extensional deformation and exhumation during the CretaceousCenozoic; these lineaments also partitioned contractional deformation during the Permo-Triassic Hunter-Bowen Orogeny (Holcombe et al.,

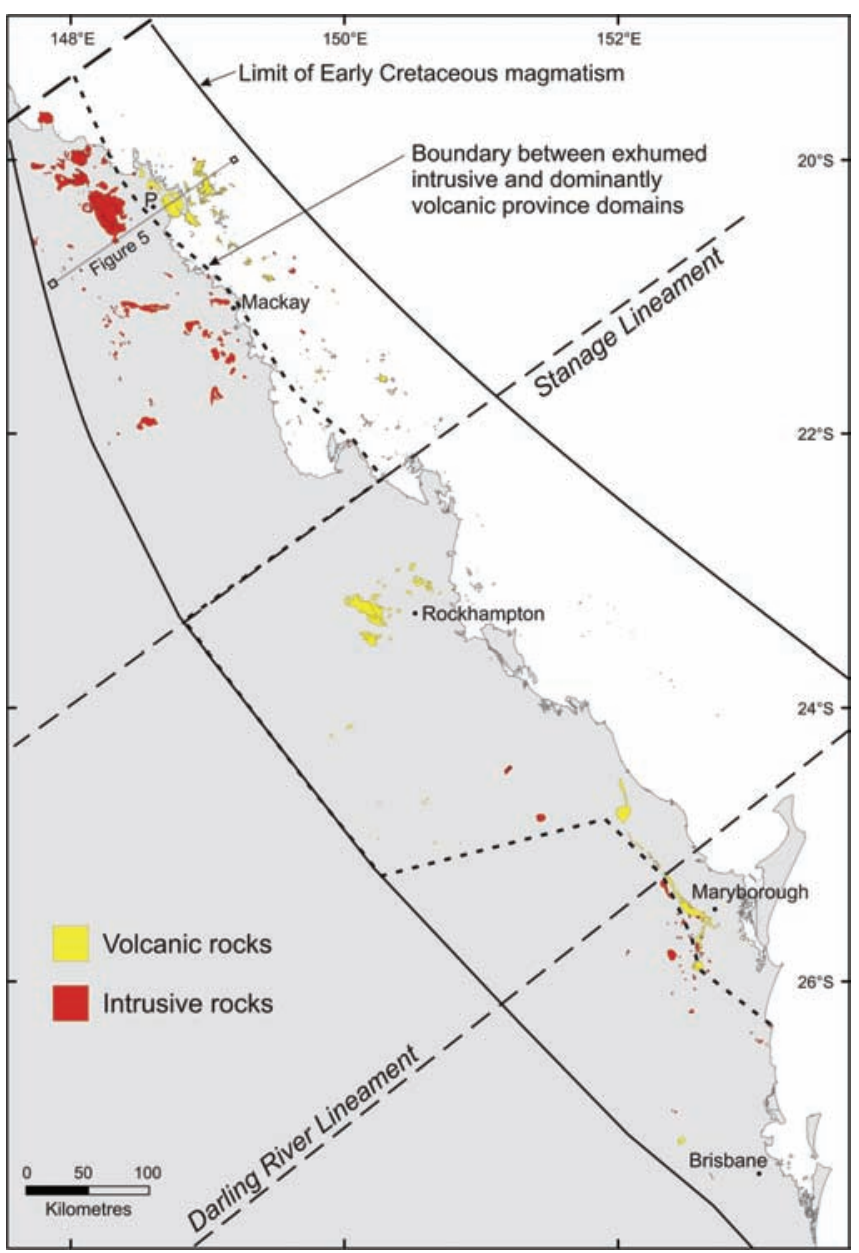

Figure 3 New distribution map of Early Cretaceous igneous units in Queensland, based on new mapping and dating. Different erosional levels occur along the Queensland margin and dominantly volcanic versus dominantly intrusive domains can be recognised, which are related to major cross-orogen lineaments. P, Proserpine. 
1997). The distribution of Cenozoic intraplate volcanics (Figure 2) and the watershed of the Great Dividing Range (passive margin mountain range) in part mirror this along margin partitioning.

\section{Volcanic Geology}

Lithologically, the Whitsunday Volcanic Province is volumetrically dominated by welded dacitic-rhyolitic and relatively lithic-rich ignimbrite (Bryan et al., 2000), and most exposures often present monotonous sequences of stacked, welded ignimbrite units forming km-thick sections in the northern part of the province. The eruptive powerhouses of the province were several, relatively large (10-20 km diameter) calderas that form a NW-trending belt through the northern part of the province. Some intracaldera ignimbrite units are up to $1 \mathrm{~km}$ thick (Clarke et al., 1971; Ewart et al., 1992; Bryan et al., 2000), whereas extracaldera units are 10 s to less commonly, 100s metres thick. Coarse lithic lag breccias containing clasts up to $6 \mathrm{~m}$ diameter (Ewart et al., 1992) cap the ignimbrites in proximal sections and record caldera collapse episodes. Exhumed caldera sections (e.g., Whitsunday Island) reveal multiple caldera-forming ignimbrite eruptions producing caldera fill successions of at least 3-4 km thick. Several calderas were flooded, being occupied by shallow lakes and rhyolite domes during eruptive hiatuses. Phreatomagmatic eruptive phases characterised some caldera-forming eruptions as a result of explosive magma interaction with the caldera lakes. Intercalated with the silicic pyroclastic rocks are basaltic and silicic lavas, with andesite-dacite lavas rare. Basalt lavas are uncommon in island (eastern) exposures but are volumetrically more abundant in mainland (western) exposures. Associated with the volcanics are locally significant thicknesses of coarse volcanogenic conglomerate and sandstone (Clarke et al., 1971; Bryan et al., 2000). The sedimentary rocks are texturally and compositionally immature, reflecting the local volcanic provenance, and sedimentation appears to have been in poorly confined, high-energy alluvial environments or caldera lakes. Dyke swarms and sills are an integral feature of the volcanic sequences, with individual dykes ranging up to $50 \mathrm{~m}$ in thickness, and have a strong N-S orientation (Ewart et al., 1992; Bryan et al., 2000, 2003). Silicic dykes predominate in the exhumed caldera sections, whereas mafic dykes and sills are more abundant in central and western exposures where basaltic lavas are also more common. Early Cretaceous granites also intrude the volcanic sequences (Figure 3). Overall, the volcanic sequences record a multiple vent, but calderadominated, low-relief volcanic region (Bryan et al., 2000).

\section{Geochemistry}

Chemically, the igneous suite ranges continuously from basalt to high-silica rhyolite, with calc-alkali to high-K affinities (Ewart et al., 1992; Bryan, 2007). In detail, however, this range is defined by dyke compositions (Figure 4); lavas are bimodal (basalt-andesite and rhyolite to high-silica rhyolite), and ignimbrites are dominantly rhyolitic in composition. It should be noted that the geochemical data set is biased towards the volumetrically minor lavas and dykes (311 out of 585 analyses), and when volume considerations are taken into account, igneous rock compositions within the province are overwhelmingly silicic.

The range of compositions has been generated by two-component magma mixing and fractional crystallization superimposed to produce the rhyolites (Ewart et al., 1992). The two magma components are:

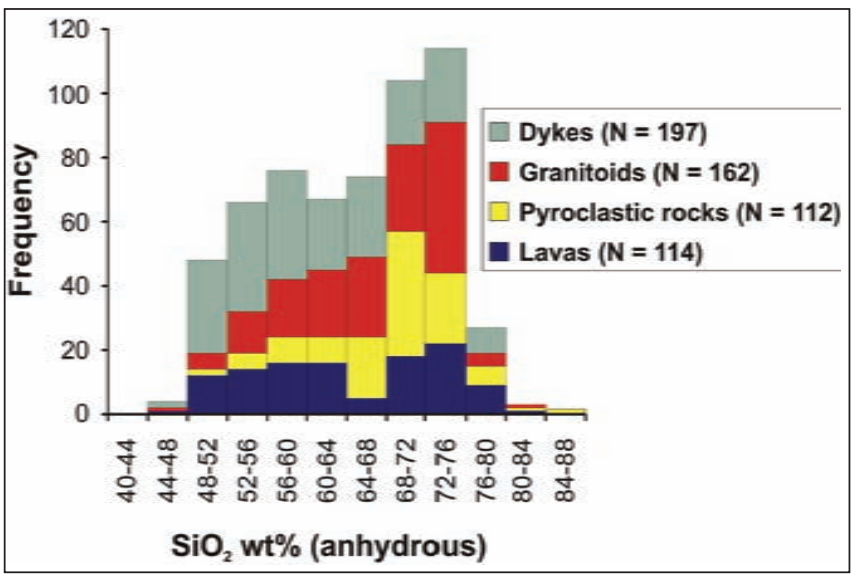

Figure 4 Silica histogram showing the distribution of compositions within dykes, lavas, pyroclastic rocks, and coeval granitoid rocks from the Whitsunday Volcanic Province (585 analyses).

(1) a volumetrically dominant partial melt of relatively young (Mesozoic-Paleozoic), non-radiogenic calc-alkaline crust; and (2) a within-plate tholeiitic basalt of E-MORB (Enriched-Mid Oceanic Ridge Basalt) affinity, and similar to the Cenozoic intraplate basalts of eastern Australia (Ewart et al., 1992; Bryan, 2007). A critical point to emphasise is that the calc-alkaline and arc-like signatures have been inherited from the crustal source, and do not provide any constraints on the (Early Cretaceous) tectonic setting in which the magmas were produced (e.g., Roberts and Clemens, 1993). The volumetric dominance of silicic igneous compositions reinforces the point that Early Cretaceous magmatism reflected a massive partial melting event of the continental crust.

\section{Geochronology}

Relatively limited $\mathrm{K} / \mathrm{Ar}$ and $\mathrm{Rb} / \mathrm{Sr}$ isotopic dating of the Whitsunday Volcanic Province has established an age range of 132$95 \mathrm{Ma}$ (Figure 5), but with a main period of igneous activity indicated between 120 and $105 \mathrm{Ma}$ (Ewart et al. 1992; Bryan et al., 1997). Other K/Ar age data from eastern Queensland (e.g., Green and Webb, 1974; Allen et al., 1998) suggest precursory magmatic activity may have begun as early as $145 \mathrm{Ma}$, although $\mathrm{U} / \mathrm{Pb}$ zircon dating has as yet, not duplicated these older ages. However, it is being increasingly

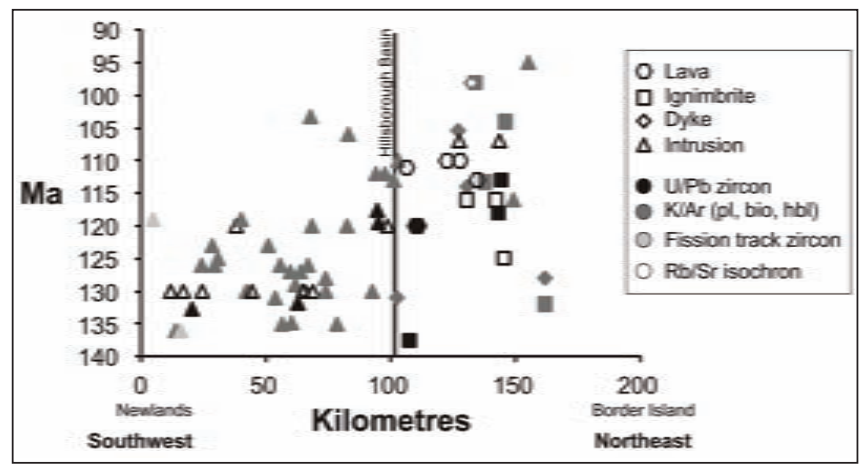

Figure 5 Space-time presentation of age data from the northern Whitsunday Volcanic Province (updated from Bryan et al., 1997). Ages have been projected onto a SW-NE cross-section (see Figure 3), from the mainland (Newlands) to outer islands (Border Island). Age data are distinguished in terms of lithology and dating method. 


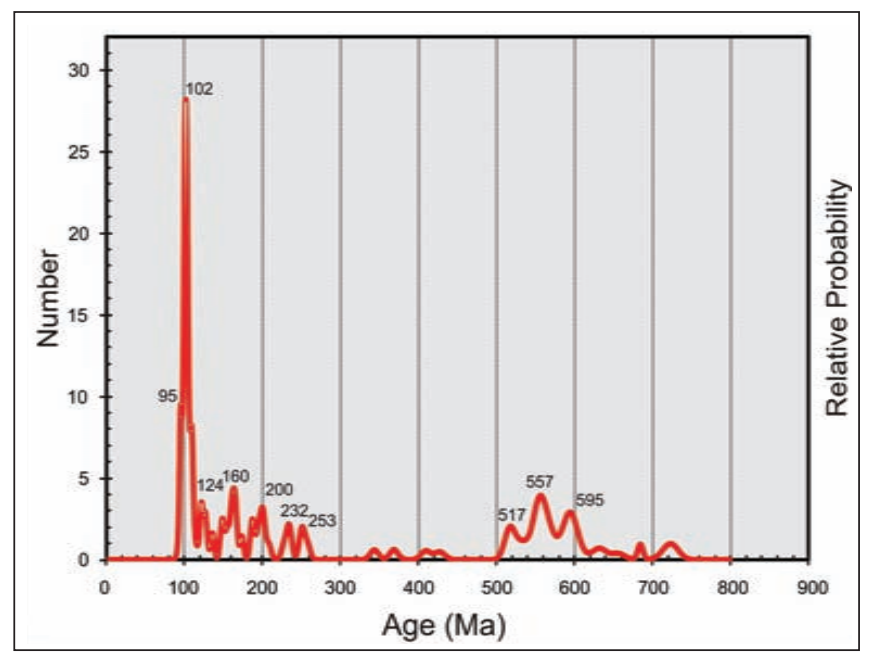

Figure 6 Probability-density distribution plot of detrital zircon ${ }^{208} \mathrm{~Pb}$ corrected ${ }^{206} \mathrm{~Pb} /{ }^{238} \mathrm{U}$ ages $<900 \mathrm{Ma}$ from the latest AlbianCenomanian Winton Formation of the Great Australian Basin system (Greentree, 2011). Sample is $700 \mathrm{~km}$ WSW from the centre of the Whitsunday Silicic LIP. Zircon ages <130 Ma are from euhedral zircons, highly rounded and abraded zircons yielded ages between $400 \mathrm{Ma}$ and $2.8 \mathrm{Ga}$ (Greentree, 2011). Plot contains 107 concordant ages.

recognised that some Late Jurassic and Early Cretaceous K/Ar ages are reset ages (e.g., Allen et al., 1998; Uysal et al., 2001) due to the major thermal event associated with Silicic LIP magmatism (e.g., as evidenced by Early Cretaceous heating in the apatite fission track data for eastern Australia). Preliminary LA-ICP-MS U/Pb zircon dating of ignimbrites from the Whitsunday Volcanic Province (Bryan and Allen, unpublished data, 2005) supports the notion of a main period of activity between 120-105 Ma, and pulses are indicated between c. 118-113 and c. 110-105 Ma (Bryan and Ernst, 2008). However, a detrital geochronology study of the coeval (latest Albian-Cenomanian) volcanogenic Winton Formation in the Great Australian Basin system has recognised a dominant volcanic and euhedral detrital zircon component of c. 105-95 Ma (Figure 6). These ages, their general absence from the Whitsunday Silicic LIP, but widespread occurrence in age spectra of Mesozoic-Cenozoic basins and sediments (e.g., Sircombe, 1999; Cross et al., 2010), and the exhumation history of the Queensland margin (Figure 3) implies a substantial missing section exists in the Whitsunday Volcanic Province, which is now preserved in adjacent sedimentary basins. The new detrital zircon ages thus reinforce a young pulse of silicic explosive volcanism between 105-100 Ma, and the continuation of significant rhyolitic ignimbrite volcanism to c. $95 \mathrm{Ma}$.

The LA-ICP-MS studies have identified zircon xenocrysts with ages of c. 490 and $787 \mathrm{Ma}$. These inherited $\mathrm{U} / \mathrm{Pb}$ ages are consistent with the $\mathrm{Nd}$ model $\mathrm{T}_{\mathrm{DM}}$ ages of 200-600 Ma calculated for the magma crustal sources (Ewart et al., 1992). Considerably more geochronological work is required to understand the eruptive history of the province, in particular to constrain better, crustal sources, melt production rates, and eruptive volume and composition relationships with time.

\section{Igneous rocks of southeast Australia}

Minor volumes of Early Cretaceous igneous rocks are preserved along the SE margin of Australia (Figure 2) with the most prominent example being the Mount Dromedary ring complex (e.g., Smith et al., 1988; Nott and Purvis, 1995). Early Cretaceous intrusions, most likely related to the Mount Dromedary igneous complex have also been dredged from the continental slope off southern New South Wales (Hubble et al., 1992). The rocks along the SE Australian margin tend toward bimodal compositions, occurring as basalt-basanite lavas and dykes and monzonite-syenite intrusions and trachytic to rhyolitic volcanics. Overall, igneous compositions are slightly more alkaline than coeval igneous rocks from the Whitsunday Volcanic Province to the N (Smith et al., 1988; Middlemost et al., 1992). Igneous ages are mostly between c. 110-90 Ma (Figure 2; Jones and Veevers, 1983, Middlemost et al., 1992; Hubble et al., 1992). More substantial volumes of Early Cretaceous igneous rock existed along the SE margin, but have subsequently been rifted away and are now located in submerged rift basins on the Lord Howe Rise on the eastern side of the Tasman Basin. The strong increase in maximum Cretaceous paleotemperatures towards the SE margin as evidenced by apatite fission track data (e.g., Kohn et al., 2002) and thermally reset K/Ar ages of fault-related illite at c. $120 \mathrm{Ma}$ in the Sydney region (Och et al., 2009) provide indirect evidence that a major igneous belt was located close to the SE margin during the Early Cretaceous.

\section{Great Australian Basin system}

In addition to voluminous silicic volcanism, the Cretaceous geological history of eastern Australia is marked by the development of extensive sedimentary basins (Figure 1), most notably the Great Australian Basin system. The latest Triassic-Cretaceous Great Australian Basin (GAB) system covers $22 \%$ of Australia, but the preserved remnants of this intracratonic basin system and the stratigraphy of other, now isolated areas of Jurassic-Cretaceous outcrop suggest the GAB may have originally covered a much larger area of eastern Australia (Fielding et al., 1996). The various components of the GAB (Eromanga, Surat, Carpentaria, Laura and Clarence-Moreton basins) preserve Early Cretaceous (AptianCenomanian), volcanogenic sedimentary rocks that cover $>2 \mathrm{Mkm}^{2}$ to an average thickness of $500 \mathrm{~m}$. The volcanogenic sedimentary rocks are dominantly mudstone, siltstone and sandstone that were deposited in environments ranging from fluvial/lacustrine to coastal plain and shallow marine (Smart and Senior, 1980; Hawlader, 1990; Fielding, 1992; Greentree, 2011). This volcanogenic sedimentation represents an abrupt and fundamental change in sediment provenance from underlying (Neocomian), basement-derived quartzose sandstones (Bryan et al., 1997). Volcanogenic sandstones form the Surat Basin are feldspathic-lithic, with an average Q:F:L ratio of 15:41:44, and volcanic lithic grains represent more than $90 \%$ of the total lithic component (e.g., Hawlader, 1990). Paleocurrent data indicate an easterly source (the Whitsunday Silicic LIP) for sediment (Hawlader, 1990; Greentree, 2011). The sheet-like external and internal geometries of the Aptian-Albian formations within the GAB suggest that predominantly passive, thermal subsidence (Fielding, 1996) coincided with volcanism along its eastern margin.

\section{Otway-Gippsland-Bass Basin System}

The WNW-trending Otway, Gippsland and Bass basins in SE Australia (Figures 1 and 2) are transtensional rift basins that form the eastern extremity of a complex rift system (Southern Rift System of 
Willcox and Stagg, 1990), which extended along the length of the southern margin of Australia during the Late Jurassic-Early Cretaceous. Their formation represents a precursor stage to the postmid Cretaceous break-up of Australia and Antarctica (e.g., Falvey and Mutter, 1981). These basins are significant for containing >2.5 $\mathrm{km}$ thickness of Aptian-Albian age volcanogenic sandstone and mudstone, but significantly, the source volcanism was unrelated to Australia-Antarctic rifting.

As in the GAB, this volcanogenic sedimentation represented a fundamental change in provenance from underlying basement-derived quartz-rich sandstones, such that volcanogenic sedimentation was essentially to the exclusion of basement-derived material (Gleadow and Duddy, 1980). Paleocurrent data indicate the source of the volcaniclastic sediment lay outside and to the $\mathrm{E}$ of the Gippsland Basin (the easternmost basin; Bryan et al., 1997). The volcanogenic sandstones are dominantly volcanic lithic, with detrital minerals of predominantly plagioclase, with lesser quartz, hornblende, pyroxene (augite), apatite, titanite, and zircon. Fission track dating of apatite, titanite, and zircon supports a contemporaneous volcanic source for the sediment (Gleadow and Duddy, 1980), and is reinforced by palynological dating that indicate the volcanogenic sandstones are Aptian-Albian in age.

\section{Submerged volcanic and rift-fill sequences on marginal continental plateaux and troughs}

It has previously been suspected by several workers that a substantial volume of Early Cretaceous igneous and volcanogenic sedimentary material may be present in submerged rift basins along the eastern margin of Australia. This was based largely on seismic studies (e.g., Falvey and Mutter, 1981), and the existence of c. $97 \mathrm{Ma}$ rhyolites recovered from deep sea drilling of the Lord Howe Rise (Figure 1; site 207, DSDP Leg 21; McDougall and van der Lingen, 1974; Tulloch et al., 2009). The amount of geophysical data has greatly increased over the last 15 years, permitting a more detailed regional evaluation of these offshore regions. Three major rift basin systems are indicated to contain Early Cretaceous rift fill offshore from eastern Australia: the Central and Western Rift Provinces (Stagg et al., 1999) of the Lord Howe Rise off SE Australia, and the Queensland and Townsville Basins off NE Australia (Figure 1).

\section{Lord Howe Rise}

The Lord Howe Rise (LHR) is a continental 'ribbon' or microcontinent $1,600 \mathrm{~km}$ long and 400-500 km wide, extending southward from the eastern Coral Sea to the western margin of New Zealand (Figure 1; Willcox et al., 2001). It became separated from the SE margin of Australia following sea floor-spreading in the Tasman Basin (e.g., Gaina et al., 1998). It has been divided into several basins and blocks by Stagg et al. (1999) based on satellite gravity and limited seismic profiles. On the western side of the LHR is an extensive rift basin system 150-250 km wide (Central and Western Rift provinces; Figure 1) that in plate reconstructions of the LHR against eastern Australia, would have extended along the SE margin of Australia, and adjacent to the Gippsland Basin (Willcox et al., 2001). Several seismic megasequences have been recognised and correlated with known megasequences of basins on the SE Australian margin (Willcox and Sayers, 2001). Significantly, the seismic data indicate N-Strending graben development along the western LHR during the latest
Jurassic-Early Cretaceous. Infill is inferred to have been initially by volcanics and then syn-rift sediments that average $1.5-3 \mathrm{~km}$ in thickness, but reach a maximum of $4+\mathrm{km}$ thickness in the deepest basins. This phase of syn-rift sedimentation has been correlated with the Early Cretaceous Otway/Strzelecki Groups and volcanogenic sandstones of the Otway-Gippsland basins (Willcox and Sayers, 2001). Furthermore, volcanic bodies are interpreted to form significant parts of the rift fill in some basins (Willcox et al., 2001).

\section{Queensland and Townsville Basins}

The Queensland and Townsville basins are two major rift basins within a large, submerged extensional continental terrane off the NE margin of Australia (Figure 1). Prior to Late Cretaceous-Cenozoic break-up, a continental mass of c. $700 \mathrm{~km}$ width existed adjacent to the margin (Draper et al., 1997). The Queensland and Townsville basins are part of a complex rift system that probably began to form in the Late Jurassic-Early Cretaceous, and now coincide with major bathymetric troughs where water depths vary from c. 1-2 km (Wellman et al., 1997). The Queensland Basin represents a northern strike continuation of the Whitsunday Volcanic Province. In contrast, the Townsville Basin is distinctive in striking E-W across the margin (Figure 1), and is thought to have formed through overall oblique NW-SE extension (Wellman et al., 1997). Control by NE-trending lineaments (Figure 3) on basin opening is also likely. These rift basins are c. $100 \mathrm{~km}$ wide, and on the basis of seismic and gravity data, contain rift valley sequences up to $3 \mathrm{~km}$ thick, of which $1 \mathrm{~km}$ is Cretaceous in age (Taylor and Falvey, 1977; Falvey and Mutter, 1981). Presently, there is no information available on the character of the Cretaceous rift fills to the basins, but are likely to be volcanic and volcanogenic sedimentary rocks as in the adjacent Whitsunday Volcanic Province and Great Australian Basin system, as well as most likely recording the erosional unroofing of the Whitsunday Silicic LIP after $100 \mathrm{Ma}$.

\section{New Caledonia}

A recent $\mathrm{U} / \mathrm{Pb}$ detrital zircon geochronology study of Mesozoic greywacke terranes in New Caledonia (Figure 1) has revealed the significant presence of Early Cretaceous age zircons derived from a contemporary silicic volcanic source (Adams et al., 2009: Cluzel et al., 2012). Statistically significant detrital zircon age populations include: $102 \pm 4 \mathrm{Ma}$ (33\% of dated population); $119 \pm 2 \mathrm{Ma}$ (18\% of dated population); $108 \pm 2 \mathrm{Ma}(57 \%)$ and $123 \pm 4 \mathrm{Ma}(18 \%)$. The youngest age populations are remarkably similar to the detrital zircon age spectra from the Winton Formation (Figure 6).

\section{Discussion}

\section{Revised volume estimates}

An extrusive volume of $>1.5 \mathrm{Mkm}^{3}$ was estimated for Whitsunday Silicic LIP magmatism by Bryan et al. (1997). This was based on the preserved volumes of volcanogenic sediment in the GAB system ( $>1$ $\left.\mathrm{Mkm}^{3}\right)$, the Otway-Gippsland Basins $\left(>0.4 \mathrm{Mkm}^{3}\right)$ and the Whitsunday Volcanic Province $\left(>0.1 \mathrm{Mkm}^{3}\right)$. A variety of new data are now available permitting a reassessment of extrusive volumes from the Whitsunday Silicic LIP. Revised volume estimates are given in Table 1. 
Table 1 Revised volume estimates for the Whitsunday Silicic Large Igneous Province.

\begin{tabular}{lc}
\hline Tectonic Element & $\begin{array}{c}\text { Preserved volume of } \\
\text { volcanic material }\left(\mathrm{km}^{3}\right)\end{array}$ \\
\hline Whitsunday Volcanic Province $^{1}$ & $>5.4 \times 10^{5}$ \\
Southeast Australia & $\leq 10^{2}$ \\
Otway-Gippsland Basins & $>4 \times 10^{5}$ \\
Great Australian Basin & $>1 \times 10^{6}$ \\
Townsville-Queensland Basins ${ }^{2}$ & $>1 \times 10^{5}$ \\
Lord Howe Rise & $>4.5 \times 10^{5}$ \\
Total & $2,490,100$
\end{tabular}

1. An average thickness of $3 \mathrm{~km}$ is used to estimate preserved extrusive volumes for the $>900 \times 200 \mathrm{~km}$ silicic volcanic belt along the Queensland coast.

2. Volume is based on basin extents of $1000 \times 100 \mathrm{~km}$ and Early Cretaceous rift fill of $1 \mathrm{~km}$.

3. Volume is calculated for the c. $1500 \times 150-200 \mathrm{~km}$ wide rift basin system (Central and Western Rift provinces of Stagg et al., 1999) that contains on average, $1.5-3 \mathrm{~km}$ thickness (2.25 to $6.75 \times 10^{5} \mathrm{~km}^{3}$ ) of Early Cretaceous rift fill (Willcox et al., 2001). A conservative thickness of $2 \mathrm{~km}$ is used in volume calculations.

Initial volume estimates for the Whitsunday Volcanic Province were based on an average thickness of $1 \mathrm{~km}$, but further stratigraphic work indicates preserved thicknesses to be in the order of 3-4+ km (Bryan et al., 2000). The detrital zircon age data from the Winton Formation, indicating a significant pulse of rhyolitic ignimbrite volcanism from 105-100 Ma, and the general absence of rocks of this age in the province indicates a substantial missing section to the Whitsunday Silicic LIP. Of note is that Smart and Senior (1980) estimated that a volcanic belt of 3,000 × $130 \times 2 \mathrm{~km}$ was required to account for the volume of detritus preserved in the GAB system alone. The major addition to the revised volume estimate is that of volcaniclastic rock preserved in the 1,500 x 150-200 km rift basin system of the Lord Howe Rise (Stagg et al., 1999; Willcox et al., 2001; Willcox and Sayers, 2001). A similar volume to that preserved along the SE Australian margin (Otway-Gippsland basins) is indicated. Importantly, the occurrence of Early Cretaceous volcanogenic sediment in New Caledonia (Adams et al., 2009) raises the possibility that the dispersal area of volcanogenic sediment and volume of volcanic material produced are probably greater still than the revised estimates presented here. In summary, minimum igneous volumes of the Whitsunday Silicic LIP, including volcanic and coeval volcanogenic sedimentary rock, preserved along the eastern Australian margin are estimated to be $>2.5 \mathrm{Mkm}^{3}$.

\section{Importance of the sedimentary record}

The Whitsunday Silicic LIP is unusual in that a large proportion of its products are preserved as huge volumes $\left(>1.4 \mathrm{Mkm}^{3}\right)$ of coeval volcanogenic sediment in adjacent continental sedimentary basins (Figure 3; Bryan et al., 1997). The additional preservation of $>0.55$ $\mathrm{M} \mathrm{km}$ of volcaniclastic material is now indicated for offshore rift basins (Figure 4). Such substantial volumes of coeval volcanogenic sediment are not characteristic of other LIPs and volcanic rifted margins (cf. Menzies et al., 2002). Age dating of volcanic mineral grains (e.g., Gleadow and Duddy, 1980; Fig 6), the fresh nature of the detrital mineral grains and the sheer volume of volcanogenic sediment in the Otway-Gippsland and GAB systems preclude any arguments for an igneous basement-derived source for the sediment. An important issue then is how such huge volumes of predominantly sand-grade volcanogenic sediment were rapidly generated and transported over large distances $(>500 \mathrm{~km})$ and low-relief gradients with limited weathering (Smart and Senior, 1980) and textural maturation to fundamentally alter the basin fill history and reservoir potential of several widely separate and tectonically unrelated sedimentary basin systems.

In a comparison of volcanic phenocryst compositions from the Whitsunday Volcanic Province with detrital mineral grains from the coeval volcanogenic sedimentary formations of the Great Australian and Otway-Gippsland basin systems, Bryan et al. (1997) demonstrated that it was phenocryst compositions from the volumetrically dominant dacitic-silicic ignimbrites that matched the detrital volcanic mineral grain compositions. This overlap confirmed that silicic pyroclastic volcanism was the major expression of Whitsunday Silicic LIP magmatism in eastern Australia and sediment source. Furthermore, the overlap implied there was a remarkable consistency in mineral composition, and consequently, whole rock chemistry for Whitsunday Silicic LIP magmatism, particularly considering that volcanism and sedimentation were occurring over a distance of $>2,500 \mathrm{~km}$ along the eastern Australian margin.

For the Whitsunday Silicic LIP, there were two important reasons why there was such an important sedimentary record of magmatism. The first was the fortuitous circumstance that two major pre-existing continental sedimentary basins were adjacent to the province, and able to accommodate huge volumes of volcanogenic sediment. A marine transgression during the Aptian-Albian further facilitated sediment accumulation in the GAB system. However, an increased flux of volcanogenic sediment in the late Albian helped drive a basinwide regression as recorded by the Winton Formation (e.g., Gallagher and Lambeck, 1989). The intersection of the newly developing N-S volcanic rift system along eastern Australia with the E-W AntarcticAustralian rift to the $\mathrm{E}$ of the Gippsland Basin, allowed the shedding of volcanic material towards the $\mathrm{W}$ into the Otway-Gippsland basin system that was entering a sag phase of basin development. The second reason was that the pyroclastic mode of fragmentation and dispersal was a critical factor in producing large volumes of sand-grade sediment to be rapidly delivered into the continental basin systems. Large volumes of easily erodible, nonwelded pyroclastic debris were likely present along the flanks of the province that could be remobilised by efficient W-draining fluvial systems. The hydrology of drainage basins are substantially affected by explosive volcanism as opportunities for sediment erosion and transport are greatly increased resulting in prolonged and extreme sediment yields in rivers (e.g., Gran and Montgomery, 2005). In contrast, only minor volumes of coarse fragmentary material (e.g., a' a' lava breccias, scoria deposits) tend to be produced during subaerial flood basalt eruptions in continental flood basalt provinces. The quick burial of brecciated material by succeeding lava flows combined with the generally coherent (unfragmented) nature of the flood basalt lavas are important factors for why continental flood basalt provinces have a limited sedimentary response.

\section{Volcanic and compositional trends}

Volcanic stratigraphic studies of the Whitsunday Volcanic Province (Bryan et al., 2000) highlight some important longer term trends in volcanism and erupted compositions. Although a range of 
igneous compositions are present (Figure 4), stratigraphic constraints indicate two important temporal compositional trends:

1) volcanism first evolving towards more bimodal compositions with time; and

2) the development of a late-stage, low-volume, largely intrusive phase dominated by intermediate (andesitic) magma compositions.

The compositional trend towards bimodalism is a more common characteristic of magmatism associated with continental rifting. Early phases of volcanism (c. 130-115 Ma) were dominantly explosive, erupting dacitic to rhyolitic magmas, whereas volcanism during later stages ( $<115 \mathrm{Ma})$ was both effusive and explosive, when mainly basaltic and rhyolitic lavas were erupted contemporaneously with predominantly rhyolitic to high-silica rhyolite ignimbrites (Bryan et al., 2000). Mafic magma compositions became less contaminated with time, with intrusion of primitive E-MORB gabbros occurring later in the igneous history. More crystal-rich and quartz-, biotite- and hornblende-bearing rhyolitic magmas are also more common in the upper parts of the stratigraphy. Further indication of this trend toward more mafic and alkaline compositions is evident from the c. 110-90 Ma igneous rocks along the SE Australian margin, and then the eruption of intraplate alkali volcanics beginning c. $80 \mathrm{Ma}$.

However, field relationships further indicate that at least within the province, bimodal volcanism was post-dated by a largely intrusive phase represented by more intermediate magma compositions. Andesitic compositions across the province are largely restricted to dykes (Figure 4) and represent an insignificant proportion of the total magma volume emplaced. Field relationships constrain much of the andesitic dyking to post-date the early silicic and later bimodal volcanic phases, and thus indicate a final phase of low-volume andesitic dyking focussed on the central part of the province. This final phase is interpreted to reflect an increased rate and focussing of rifting, which enhanced the disruption of magma systems such that magma mixing and emplacement of hybridised magmas was promoted by syn-volcanic faulting (e.g., Johnson and Grunder, 2000; Bryan et al., 2011).

\section{Summary}

The Whitsunday Silicic LIP formed a linear silicic-dominated igneous belt several hundred kilometres inboard of the continental margin and thus resembles the Jurassic Ferrar LIP along strike to the $\mathrm{S}$ in terms of province geometry and relative position to the continental margin. LIP magmatism (c. 35 Myrs) and continental rifting (1530 Myrs) was protracted before complete rupture of the continent and onset of sea-floor spreading at $84 \mathrm{Ma}$. Significant records of this Silicic LIP and rifting event are preserved in onshore and offshore sedimentary basins and complement the preserved onshore igneous components. Integrating the onshore and offshore records of volcanic rifted margins are vital to fully understand rift architecture, timing and evolution, the duration and magnitude of igneous activity, their potential environmental impact and for evaluating their resource potential.

\section{Acknowledgements}

Scott Bryan thanks Tony Ewart for valuable discussions over many years. James Greentree has been supported by a QUT Vacation
Research Experience Scholarship, and Coralie Siegel by a QUT Vice Chancellors Research Fellow PhD Scholarship and the Queensland Geothermal Energy Centre of Excellence at The University of Queensland. Detrital zircon age data were manipulated and graphed using the Isoplot version 3.00 add-in for Microsoft Excel $^{\mathrm{TM}}$ by Ken Ludwig, Berkeley Geochronology Centre. Richard Ernst and Dougal Jerram are thanked for constructive and supportive reviews of this manuscript.

\section{References}

Adams, C.J., Cluzel, D. and Griffin, W.L., 2009, Detrital-zircon ages and geochemistry of sedimentary rocks in basement Mesozoic terranes and their cover rocks in New Caledonia, and provenances at the Eastern Gondwanaland margin: Australian Journal of Earth Sciences, v. 56, pp. 1023-1047.

Allen, C.M., Williams, I.S., Stephens, C.J. and Fielding, C.R., 1998, Granite genesis and basin formation in an extensional setting: the magmatic history of the northernmost New England Orogen: Australian Journal of Earth Sciences, v. 45, pp. 875-888.

Armitage, J.J., Collier, J.S. and Minshull, T.A., 2010, The importance of rift history for volcanic margin formation: Nature, v. 465, pp. 913-917.

Baker, J.C., Bai, G.P., Hamilton, P.J., Golding, S.D. and Keene, J.B., 1995, Continental scale magmatic carbon-dioxide seepage recorded by dawsonite in the Bowen-Gunnedah-Sydney Basin System, Eastern Australia: Journal of Sedimentary Research, v. 65, pp. 522-530.

Bryan, S.E., 2007. Silicic Large Igneous Provinces: Episodes, v. 30, pp. 20 31.

Bryan, S.E. and Ernst, R.E., 2008, Revised definition of Large Igneous Provinces (LIPs): Earth Science Reviews, v. 86, pp. 175-202.

Bryan, S.E., Constantine, A.E., Stephens, C.J., Ewart, A., Schön, R.W. and Parianos, J., 1997, Early Cretaceous volcano-sedimentary successions along the eastern Australian continental margin: implications for the break-up of eastern Gondwana: Earth and Planetary Science Letters, v. 153 , pp. $85-102$.

Bryan, S.E., Ewart, A., Stephens, C.J., Parianos, J. and Downes, P.J., 2000, The Whitsunday Volcanic Province, central Queensland, Australia: Lithological and stratigraphic investigations of a silicic-dominated large igneous province: Journal of Volcanology and Geothermal Research, v. 99 , pp. $55-78$.

Bryan, S.E., Fielding, C.R., Holcombe, R.J., Cook, A. and Moffitt, C.A., 2003, Stratigraphy, facies architecture and tectonic implications of the Upper Devonian to Lower Carboniferous Campwyn Volcanics of the northern New England Fold Belt: Australian Journal of Earth Sciences, v. 50 , pp. $377-401$.

Bryan, S., Ferrari, L., Ramos Rosique, A., Allen, C., Lopez, M., Orozco, T. and Peláez, J., 2011, Consequences of extensional tectonics on volcanic eruption style, compositions and source regions: new insights from the southern Sierra Madre Occidental and Gulf of California regions, western Mexico: International Union of Geodesy and Geophysics General Assembly, Abstract.

Clarke, D.E., Paine, A.G.L. and Jensen, A.R., 1971, Geology of the Proserpine 1:250,000 Sheet area, Queensland: BMR Geology and Geophysics, Report 144, 98 pp.

Cluzel, D., Maurizot, P., Collot, J. and Sevin, B., 2012, An outline of the geology of New Caledonia: from Permian-Mesozoic Southeast Gondwanaland active margin to Tertiary obduction and supergene evolution: Episodes (this volume).

Cross, A., Jaireth, S., Hore, S., Michaelsen, B., and Schofield, A., 2010, SHRIMP U-Pb detrital zircon results, Lake Frome region, South Australia: Geoscience Australia, Record 2009/46, 32 pp.

Draper, J.J., Wellman, P. and Symonds, P.A., 1997, Townsville Basin, in Bain J.H.C. and Draper J.J. (eds), North Queensland Geology: AGSO Bulletin 240/Queensland Geology 9, pp. 523-526.

Ewart, A., Schön, R.W. and Chappell, B.W., 1992, The Cretaceous volcanicplutonic province of the central Queensland (Australia) coast - a rift related "calc-alkaline" province: Transactions of the Royal Society of Edinburgh, Earth Sciences, v. 83, pp. 327-345. 
Falvey, D.A. and Mutter, J.C., 1981, Regional plate tectonics and the evolution of Australia's passive continental margins: BMR Journal of Geology and Geophysics, v. 6, pp. 1-29.

Fielding, C.R., 1992, A review of Cretaceous coal-bearing sequences in Australia: Geological Society of America, Special Paper, v. 267, pp. 303324.

Fielding, C.R., 1996, Mesozoic sedimentary basins and resources in eastern Australia; a review of current understanding: Geological Society of Australia, Abstracts, v. 43, pp. 180-185.

Finn, C.A., Muller, R.A. and Panter, K.A., 2005, Definition of a Cenozoic alkaline magmatic province in the southwest Pacific mantle domain and without rift or plume origin: http://www.mantleplumes.org/SWPacific. html

Gaina, C., Müller, R.D., Royer, J.-Y., Stock, J., Hardebeck, J. and Symonds, P.A., 1998, The tectonic history of the Tasman Sea: a puzzle with 13 pieces: Journal of Geophysical Research, v. 103, pp. 12,413-12,433.

Gaina, C., Müller, R.D., Brown, B.J. and Ishihara, T., 2003, Microcontinent formation around Australia: Geological Society of America, Special Paper, v. 372 , pp. $405-416$.

Gallagher, K. and Lambeck, K., 1989, Subsidence, sedimentation and sealevel changes in the Eromanga Basin, Australia: Basin Research, v. 2, pp. $115-131$

Gleadow, A.J.W. and Duddy, I.R., 1980, Early Cretaceous volcanism and the early breakup history of southeastern Australia: Evidence from fission track dating of volcaniclastic sediments, in Cresswell, M.M. and Vella P. (eds), Fifth International Gondwana Symposium: A.A. Balkema, Rotterdam, pp. 11-16.

Golab, A.N., Carr, P.F. and Palamara, D.R., 2006, Influence of localised igneous activity on cleat dawsonite formation in Late Permian coal measures, Upper Hunter Valley, Australia: International Journal of Coal Geology, v. 66, pp. 296-304.

Gran, K.B. and Montgomery, D.R., 2005, Spatial and temporal patterns in fluvial recovery following volcanic eruptions: Channel response to basinwide sediment loading at Mount Pinatubo, Philippines: Geological Society of America Bulletin, v. 117, pp. 195-211.

Green, D.C. and Webb, A.W., 1974, Geochronology of the northern part of the Tasman Geosyncline, in The Tasman Geosyncline; A Symposium: Geological Society of Australia, Queensland Division, Brisbane, pp. 275293.

Greentree, J., 2011, Palaeoenvironmental setting of dinosaur trackways in the context of the closing stages of Eromanga Basin evolution: BSc (Hons) thesis, Queensland University of Technology, Brisbane, Australia, 107 pp. (unpublished).

Hawlader, H.M., 1990, Diagenesis and reservoir potential of volcanogenic sandstones - Cretaceous of the Surat Basin, Australia: Sedimentary Geology, v. 66, pp. 181-195.

Holcombe, R.J., Stephens, C.J., Fielding, C.R., Gust, D.A., Little, T.A., Sliwa, R., Kassan, J., McPhie, J. and Ewart, A., 1997, Tectonic Evolution of the Northern New England Fold Belt: The Permian-Triassic Hunter Bowen event: Geological Society of Australia, Special Publication, v. 19, pp. 52-65.

Isern, A.R., Anselmetti, F.S., Blum, P., et al., 2002, Proceedings of the Ocean Drilling Program, Initial Reports, Volume 194.

Hubble, T.C.T., Packham, G.H., Hendry, D.A.F. and McDougall, I., 1992, Granitic and monzonitic rocks dredged from the southeast Australian continental margin: Australian Journal of Earth Sciences, v. 39, pp. 619630.

Johnson, J.A. and Grunder, A.L., 2000, The making of intermediate composition magma in a bimodalsuite: Duck Butte Eruptive Center, Oregon, USA: Journal of Volcanology and Geothermal Research, v. 95, pp. 175-195.

Johnson, R.W. (ed.), 1989, Intraplate Volcanism in Eastern Australia and New Zealand: Cambridge University Press, Sydney, 408 pp.

Jones, J.G. and Veevers, J.J., 1983, Mesozoic origins and antecedents of Australia's Eastern Highlands: Journal of the Geological Society of Australia, v. 30, pp. 305-322.

Kohn, B.P., O'Sullivan, P.B., Gleadow, A.J.W., Brown, R.W., Gallagher, K. and Foster, D.A., 2002, Shaping the Australian crust over the last 300 million years: insights from fission track thermotectonic imaging and denudation studies of key terranes: Australian Journal of Earth Sciences, v. 49 , pp. $697-718$.

Kohn, B.P., O'Sullivan, P.B., Gleadow, A.J.W., Brown, R.W., Gallagher, K. and Foster, D.A., 2003, Shaping the Australian crust over the last 300 million years: insights from fission track thermotectonic imaging and denudation studies of key terranes - Reply: Australian Journal of Earth Sciences, v. 50, pp. 646-650.

Lafoy, Y., Géli, L., Klingelhoefer, F., Vially, R., Sichler, B. and Nouzé, H., 2005, Discovery of continental stretching and oceanic spreading in the Tasman Sea: Eos, Transactions American Geophysical Union, v. 86, pp. 101, 104-105.

Lister, G.S. and Etheridge, M.A., 1989, Detachment models for uplift and volcanism in the Eastern Highlands, and their implication to the origin of passive margin mountains, in Johnson, R.W. (ed.), Intraplate volcanism in Eastern Australia and New Zealand: Cambridge University Press, Cambridge, pp. 297-313.

Marshallsea, S.J., Green, P.F. and Webb, J., 2000, Thermal history of the Hodgkinson Province and Laura Basin, Queensland; multiple cooling episodes identified from apatite fission track analysis and vitrinite reflectance data: Australian Journal of Earth Sciences, v. 47, pp. 779797.

McDougall, I. and van der Lingen, G.J., 1974, Age of the rhyolites of the Lord Howe Rise and the evolution of the southwest Pacific Ocean: Earth and Planetary Science Letters, v. 21, pp. 117-126.

Menzies, M.A., Klemperer, S.L., Ebinger, C.J. and Baker, J., 2002, Characteristics of volcanic rifted margins: Geological Society of America, Special Paper, v. 362, pp. 1-14.

Middlemost, E.A.K, Dulhunty, J.A. and Beck, R.W., 1992, Some Mesozoic igneous rocks from northeastern New South Wales and their tectonic setting: Journal and Proceedings of the Royal Society of New South Wales, v. 125 , pp. $1-11$.

Nott, J. and Purvis, A.C., 1995, Geomorphic and tectonic significance of Early Cretaceous lavas on the coastal plain, southern New South Wales: Australian Journal of Earth Sciences, v. 42, pp. 145-149.

O'Sullivan, P.B., Kohn, B.P., Foster, D.A. and Gleadow, A.J.W., 1995, Fission track data from the Bathurst Batholith; evidence for rapid Mid-Cretaceous uplift and erosion within the eastern highlands of Australia: Australian Journal of Earth Sciences, v. 42, pp. 597-607.

O’Sullivan, P.B., Coyle, D.A., Gleadow, A.J.W. and Kohn, B.P., 1996, Late Mesozoic to early Cenozoic thermotectonic history of the Sydney Basin and the eastern Lachlan fold belt, Australia: Geological Society of Australia, Abstracts, v. 43, pp. 424-432.

O'Sullivan, P.B., Kohn, B.P. and Cranfield, L., 1999, Fission track constraints on the Mesozoic to Recent thermotectonic history of the northern New England Orogen, southeastern Queensland: 1999 New England Orogen Conference, Abstracts, Armidale, Australia, pp. 285-293.

Och, D.J., Offler, R., Zwingmann, H., Braybrooke, J. and Graham, I.T., 2009, Timing of brittle faulting and thermal events, Sydney region: association with the early stages of extension of East Gondwana: Australian Journal of Earth Sciences v. 56, pp. 873-887.

Ollier, C.D., 1982, The Great Escarpment of eastern Australia: tectonic and geomorphic significance: Journal of the Geological Society of Australia v. 29 , pp. $13-23$.

Roberts, M.P. and Clemens, J.D., 1993, Origin of high-potassium, calcalkaline, I-type granitoids: Geology, v. 21, pp. 825-828.

Sircombe, K.N., 1999, Tracing provenance through the isotope ages of littoral and sedimentary detrital zircon, eastern Australia: Sedimentary Geology, v. 124 , pp. $47-67$

Smart, J. and Senior, B.R., 1980, The Jurassic-Cretaceous basins of northeastern Australia, in Henderson, R.A. and Stephenson, P.J. (eds), The Geology and Geophysics of Northeastern Australia: Geological Society of Australia, Queensland Division, Brisbane, pp. 315-328.

Smith, I.E.M., White, A.J.R., Chappell, B.W. and Eggleton, R.A., 1988, Fractionation in a zoned monzonite pluton: Mount Dromedary, southeastern Australia: Geological Magazine, v. 125, pp. 273-284.

Stagg, H.M.J., Borissova, I., Alcock, M. and Moore, A.M.G., 1999, Tectonic provinces of the Lord Howe Rise, 'Law of the Sea 'study has implications for frontier hydrocarbons: AGSO Research Newsletter, v. 31, pp. 31-32.

Storey, M., Duncan, R.A. and Swisher, C.C., 2007, Paleocene-Eocene Thermal Maximum and the Opening of the Northeast Atlantic: Science, v. 316, pp. 587-589.

Sutherland, F.L., Robertson, A.D., Barron, B.J. and Pogson, R.E., 1996, The Rockhampton Plume and its late Mesozoic trace? Geological Society of Australia, Abstracts, v. 43, pp. 519-527.

Svensen, H., Planke, S., Malthe-Sørenssen, A., Jamtveit, B., Myklebust, R., 
Eidem, T.R. and Rey S., 2004, Release of methane from a volcanic basin as a mechanism for initial Eocene global warming: Nature, v. 429, pp. 542-545.

Taylor, L.W.H. and Falvey, D.A., 1977, Queensland Plateau and Coral Sea Basin - stratigraphy, structure and tectonics: Australian Petroleum Exploration Journal, v. 17, pp. 13-29.

Thomas, D.N., Biggin, A.J. and Schmidt, P.W., 2000, A palaeomagnetic study of Jurassic intrusives from southern New South Wales; further evidence for a pre-Cenozoic dipole low: Geophysical Journal International, v. 140, pp. 621-635.

Tulloch, A.J., Ramezani, J., Mortimer, N., Mortensen, J., van den Bogaard, P. and Maas, R, 2009, Cretaceous felsic volcanism in New Zealand and Lord Howe Rise (Zealandia) as a precursor to final Gondwana break-up, in Ring U. and Wernicke B. (eds), Extending a Continent: Architecture, Rheology and Heat Budget: Geological Society of London, Special Publications, v. 321, pp. 89-118.

Umhoefer, P.J., 2011, Why did the Southern Gulf of California rupture so rapidly?-Oblique divergence across hot, weak lithosphere along a tectonically active margin: GSA Today, v. 21, doi: 10.1130/G133A.1.

Uysal, I.T., Golding, S.D. and Glikson, M., 2000, Petrographic and isotope constraints on the origin of authigenic carbonate minerals and the associated fluid evolution in Late Permian coal measures, Bowen Basin

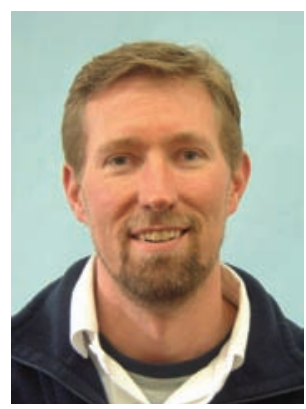

Scott Bryan is a Vice Chancellor's Research Fellow at the Queensland University of Technology in Brisbane, Australia. His research on the Early Cretaceous Whitsunday igneous province led to the recognition of silicic-dominated LIP events, and the eastern margin of Australia as a volcanic rifted margin. His research continues on several important aspects of silicic magmatism.

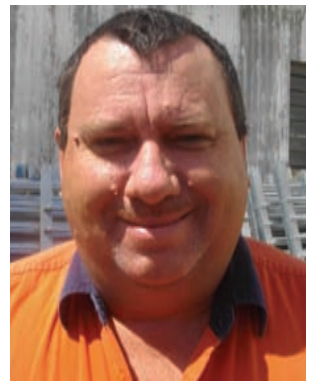

Alex Cook is Senior Curator of Geosciences at the Queensland Museum where he has worked since 1992. His diverse geo-logical interests include Paleozoic molluscs, particularly gas-tropods, trace fossils and the general Phanerozoic geology of northern Australia. He has worked extensively within the Great Artesian Basin.

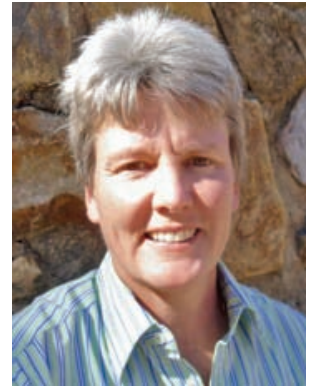

Charlotte Allen has been a senior technical officer at the Research School of Earth Sciences at the Australian National University in Canberra since 1998. Her research interests are in granitic magmatism, the New England Fold Belt, LA-ICP-MS analysis, zircon chronochemistry and $U-P b$ dating of dating of apatite, allanite, titanite and rutile.

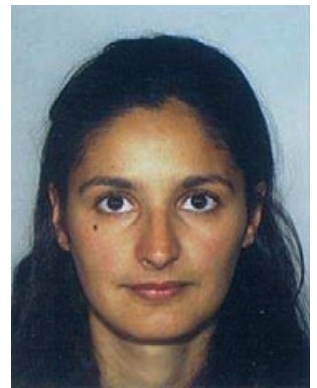

Coralie Siegel obtained a Master of Science in Geology from University Joseph Fourier, France in 2008.. Her research interests lie in petrography, petrology, volcanology, geochemistry and geochronology. Her PhD project focuses on evaluating Phanerozoic granitic rocks in Queensland for Hot Dry Rock Geothermal Systems.
(Queensland), Australia: Sedimentary Geology, v. 136, pp. 189-206.

Uysal, I.T., Golding, S.D., Bolhar, R., Zhao, J-X., Feng, Y-X., Baublys, K.A. and Greig, A., 2011, $\mathrm{CO}_{2}$ degassing and trapping during hydrothermal cycles related to Gondwana rifting in eastern Australia: Geochimica et Cosmochimica Acta, doi:10.1016/j.gca.2011.07.018

Uysal, I.T., Golding, S.D. and Thiede, D.S., 2001, K-Ar and Rb-Sr dating of authigenic illite-smectite in Late Permian coal measures, Queensland, Australia: implication for thermal history: Chemical Geology, v. 171, pp. 195-211.

Wellman, P., Struckmeyer, H.I.M., Symonds, P.A., Fellows, M.E., Scott, D.L. and Draper, J.J., 1997, Coral Sea Region, in Bain J.H.C. and Draper J.J. (eds), North Queensland Geology: AGSO Bulletin 240/Queensland Geology 9, pp. 409-418.

Willcox, J.B. and Sayers, J., 2001, Gower Basin, Lord Howe Rise: Petroleum Exploration Society of Australia, Special Publication, v. 1, pp. 189200.

Willcox, J.B., Sayers, J., Stagg, H.M.J. and van de Beuque, S., 2001, Geological framework of the Lord Howe Rise and adjacent ocean basins: Petroleum Exploration Society of Australia, Special Publication, v. 1, pp. $211-225$.

Willcox, J.B. and Stagg, H.M.J., 1990, Australia's southern margin: a product of oblique extension: Tectonophysics, v. 173, pp. 269-281.

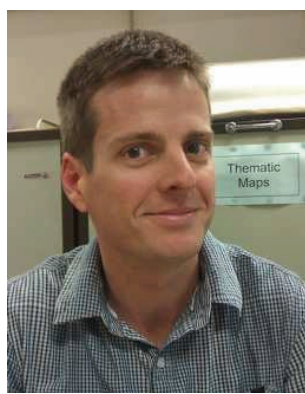

David Purdy is a senior geologist at the Geological Survey of Queensland with broad interests in igneous petrology (particularly silicic magmatism), and the tectonic development of eastern Australia. $\mathrm{He}$ is currently investigating the geology of the Thomson Orogen in Queensland and co-supervising research into the origin of high heat producing granites.

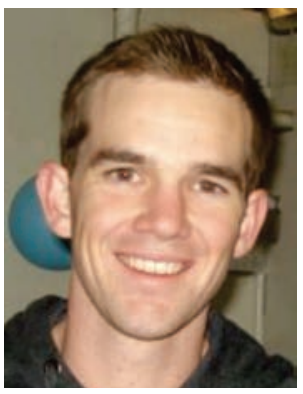

James Greentree is a recent Honours graduate in Earth Sciences from the Queensland University of Technology in Brisbane, Australia. His research interests are in clastic sedimentology, basin analysis and detrital zircon geochronology.

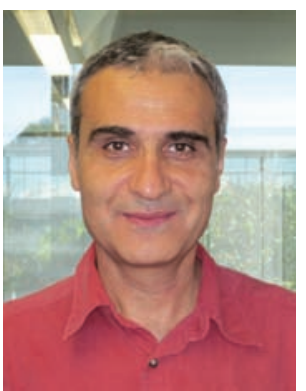

Tonguc Uysal is leader of the Reservoir Program of the Queensland Geothermal Energy Centre of Excellence at the University of Queensland. His research uses a combined application of alteration mineralogy, isotope/trace element geochemistry and geochronology to define fluid origins and reconstruct the evolution of hydrothermal systems. 